\title{
Pengaruh Leverage Terhadap Manajemen Laba Dengan Corporate Governance Sebagai Variabel Pemoderasi
}

\author{
Putu Elsa Pratiwi Dewi ${ }^{1}$ \\ Ni Gusti Putu Wirawati ${ }^{2}$ \\ ${ }^{1,2}$ Fakultas Ekonomi dan Bisnis Universitas Udayana (Unud), Bali, Indonesia \\ e-mail: elsapratiwi1997@gmail.com
}

\begin{abstract}
ABSTRAK
Tindakan manajemen laba didorong oleh beberapa faktor salah satunya leverage. Salah satu cara untuk mengurangi tindakan manajemen laba yang dilakukan oleh manajemen dengan adanya Corporate Governance yang baik dalam perusahaan. Penelitian ini bertujuan untuk mendapatkan bukti empiris mengenai pengaruh leverage terhadap manajemen laba dan kemampuan Corporate Governance dalam memoderasi pengaruh leverage terhadap manajemen laba. Penelitian ini dilakukan pada seluruh perusahaan non keuangan yang terdaftar dalam penilaian Corporate Governance Perception Index (CGPI) tahun 2011-2016. Metode penentuan sampel yang digunakan adalah menggunakan purposive sampling. Jumlah perusahaan yang memenuhi kriteria adalah 5 perusahaan dengan jumlah 30 amatan. Pengumpulan data dilakukan dengan metode observasi non partisipan. Teknik Analisis data yang digunakan yaitu uji Moderated Regression Analysis (MRA). Berdasarkan hasil penelitian, diketahui bahwa leverage berpengaruh negatif pada manajemen laba. Penelitian ini juga menemukan bahwa Corporate Governance mampu memoderasi pengaruh leverage terhadap manajemen laba.

Kata kunci: Manajemen Laba, Leverage, Corporate Governance
\end{abstract}

\begin{abstract}
Earnings management is driven by number of factors that are wrong to say leverage. One way to reduce management actions taken by management is the existence of good corporate governance in the company. This study aims to find evidence that is used to influence corporate earnings management in moderating the effect of leverage on earnings management. This research was conducted in all non-financial companies recorded in the Corporate Governance Perception Index (CGPI) in 2011-2016. The method of determining the sample used is purposive sampling. The number of companies that meet the requirements is 5 companies with 30 observations. Data collection is done by nonparticipant techniques. The data analysis technique used is Moderation Regression Analysis (MRA). Based on the results of the study, namely leverage has a negative effect on earnings management. This study also found that Corporate Governance was able to moderate the influence of leverage on earnings management.
\end{abstract}

Keywords: Earnings Management, Leverage, Corporate Governance

\section{PENDAHULUAN}

Laporan keuangan adalah bentuk tanggung jawab manajemen perusahaan atas apa yang telah dilakukan perusahaan. Informasi laba merupakan perhatian utama dalam mengukur keberhasilan atau kegagalan suatu bisnis dalam mencapai tujuan 
operasional yang telah ditentukan (Sadalia dkk., 2017). Informasi laba dapat dilihat dalam laporan keuangan perusahaan tersebut. Laporan keuangan terdiri dari neraca, laporan laba rugi, laporan arus kas, dan laporan perubahan ekuitas. Namun informasi labalah yang memiliki potensi yang sangat penting baik bagi pihak eksternal maupun internal. Informasi laba juga sering menjadi sasaran atau target rekayasa manajemen untuk mementingkan kepentingan pribadinya dan hal tersebut dapat merugikan pemegang saham atau investor (Yudiastuti \& Wirasedana, 2018).

Adanya asimetri informasi dan kecenderungan dari pihak eksternal (investor) untuk lebih memperhatikan informasi laba sebagai parameter kinerja perusahaan, akan mendorong manajemen untuk melakukan manipulasi dalam menunjukkan informasi laba (Agustia, 2013). Cara yang biasa dilakukan manajemen untuk memengaruhi angka pada laporan keuangan adalah dengan melakukan manajemen laba (Amperaningrum \& Sari, 2013). Manajemen laba adalah keputusan dari manajer untuk memilih kebijakan akuntansi tertentu yang dianggap bisa mencapai tujuan untuk meningkatkan laba atau mengurangi tingkat kerugian yang akan dilaporkan (Yudiastuti \& Wirasedana, 2018). Manajemen laba menjadi pusat perhatian bagi para pengguna laporan keuangan dalam menggunakannya. Manajemen laba merupakan keikutsertaan pihak manajemen dalam proses laporan keuangan perusahaan. Hal ini memungkinkan terjadinya dua hal yaitu, kemungkinan terjadinya penurunan laba atau kenaikan laba dengan cara manipulasi (Pasaribu dkk., 2015). Manajemen laba terjadi ketika para manajer menggunakan penilaian dalam pelaporan keuangan dan penataan transaksi untuk 
mengubah laporan keuangan untuk menyesatkan sejumlah pemangku kepentingan tentang kinerja ekonomi perusahaan, atau untuk mempengaruhi hasil kontrak yang bergantung pada angka akuntansi yang dilaporkan (Jones \& Sharma, 2001).

Salah satu kasus telah terjadi akibat dari manajemen laba seperti yang dilakukan oleh PT Kimia Farma Tbk. PT Kimia Farma diduga melakukan markup laba bersih pada tahun 2001 dalam laporan keuangannya. Kimia Farma menyebutkan berhasil memperoleh laba sebesar Rp 132 miliar. Setelah dilakukan audit ulang, pada 3 Oktober 2002 laporan keuangan Kimia Farma 2001 disajikan kembali (restated), karena telah ditemukan kesalahan yang cukup mendasar. Pada laporan keuangan yang baru, keuntungan yang disajikan hanya sebesar Rp 99,56 miliar, atau lebih rendah sebesar Rp 32,6 milyar, atau 24,7\% dari laba awal yang dilaporkan (https://davidparsaoran.wordpress.com, 2009). Selain kasus PT. Kimia Farma Tbk, PT. Katarina Utama Tbk diduga telah memanipulasi laporan keuangan sebagaimana dituduhkan oleh salah satu pemegang sahammnya yakni PT. Media Intertel Graha (MIG). Laporan keuangan 2009 yang mencantumkan pendapatan dari MIG Rp 6.773 miliar dan adanya piutang usaha dari MIG sebesar Rp 8.606 miliar (https://finance.detik.com, 2010).

Manajemen melakukan tindakan manajemen laba karena didorong oleh beberapa faktor. Salah satu faktor yang memiliki hubungan penting dengan manajemen laba dan dapat membantu para pemangku kepentingan untuk mengidentifikasi manajemen laba adalah leverage (Amidreza \& Mortazavi, 2016). Leverage adalah hutang yang digunakan oleh perusahaan untuk membiayai asetnya dalam rangka menjalankan aktivitas operasionalnya. Tinjauan literatur 
Putu Elsa Pratiwi Dewi dan Ni Gusti Putu Wirawati. Pengaruh ...

tentang manajemen laba menyoroti bahwa leverage membatasi tindakan manajemen laba. Apabila leverage meningkat akan mengurangi tindakan manajemen laba yang dilakukan oleh manajemen, hal tersebut terjadi karena beberapa alasan yaitu : 1) memanfaatkan pembayaran utang yang diperlukan, sehingga mengurangi uang tersedia bagi manajemen untuk pembelanjaan yang tidak optimal; 2) Ketika sebuah perusahaan menggunakan pembiayaan utang, ia mengalami pengawasan pemberi pinjaman dan sering tunduk pada pembatasan pengeluaran yang diinduksi oleh pemberi pinjaman (Jensen, 1986).

Terdapat penelitian mengenai pengaruh leverage terhadap manajemen laba yang dilakukan oleh (Ardison et al., 2012) yang mengatakan bahwa leverage berpengaruh positif pada tindakan manajemen laba dan hasil penelitian oleh Putri dkk. (2015) yang juga mengatakan bahwa leverage memiliki pengaruh positif pada manajemen laba, dan didukung oleh penelitian dari Gul et al. (2003) dan Prastyawan \& Saraswati (2013) yang mengatakan bahwa leverage juga berpengaruh positif terhadap tindakan manajemen laba. Namun penelitian yang dilakukan oleh Zamri dkk. (2013) mengatakan yang sebaliknya bahwa leverage berpengaruh negatif terhadap manajemen laba, pada penelitian Anggraeni \& Wardhani (2017) juga mengatakan hal yang serupa bahwa leverage berpengaruh negatif pada manajemen laba dan Bestavino (2013) juga mendapatkan hasil bahwa leverage berpengaruh negatif terhadap tindakan manajemen laba. Namun pada beberapa penelitian seperti pada Wiyadi et al. (2015), Veronica (2015), \& Amertha dkk. (2014) mengatakan bahwa leverage tidak memengaruhi tindakan manajemen laba pada suatu perusahaan. 
Berdasarkan teori keagenan, tindakan manajemen dapat diatasi atau diminimalisir melalui adanya penerapan corporate governance di perusahaan tersebut. Masalah asimetri informasi ini dapat dibatasi karena perusahaan yang menerapkan struktur dan mekanisme good corporate governance menggunakan prinsip transparansi dalam laporan keuangannya kepada pemegang saham dan publik (Putri \& Sofyan, 2013). Corporate Governance adalah konsep yang didasarkan pada teori agensi, corporate governance diharapkan berfungsi sebagai alat untuk memberikan jaminan kepada investor bahwa mereka akan menerima pengembalian dana yang telah mereka investasikan (Yuniarti et al., 2017). Secara konkret penggunaan Corporate Governance memliliki beberapa tujuan yaitu memberikan kemudahan informasi mengenai akses investasi domestik maupun asing, mendapatkan cost of capital yang lebih murah, memberikan sebuah keputusan terhadap kinerja ekonomi perusahaan, dapat meningkatkan kepercayaan stakeholder terhadap perusahaan (Almadara, 2017). Menurut Forum for Corporate Governance in Indonesia (FCGI, 2001:1) mendefinisikan good corporate governance sebagai suatu perangkat peraturan yang menetapkan hubungan antara pemegang saham, pengurus, pihak kreditur, pemerintah, karyawan serta pemegang kepentingan internal dan eksternal lainnya sehubungan dengan hak-hak dan kewajiban mereka. Menurut Organization of Economic Cooperation and Development (OECD, 2015) tujuan dari good corporate governance adalah untuk membantu perusahaan membangun kepercayaan, transparansi dan akuntabilitas yang diperlukan untuk mengembangkan investasi jangka panjang, stabilitas keuangan dan integritas bisnis, dengan mendukung 
pertumbuhan yang lebih kuat dan masyarakat yang lebih inklusif. Good corporate governance melibatkan serangkaian hubungan antara manajemen perusahaan, dewan direksi, stakeholder, dan pemangku kepentingan lainnya. Good corporate governance memiliki struktur yang menjelaskan bagaimana aturan dan prosedur dalam pengambilan dan keputusan suatu kebijakan sehingga tujuan perusahaan dan pemantauan kinerjanya dapat dipertanggungjawabkan.

Mekanisme corporate governance merupakan suatu prosedur dan hubungan yang jelas antara pihak yang mengambil keputusan dengan pihak yang melakukan kontrol atau pengawasan terhadap keputusan (Wahyono, 2012). Mekanisme good corporate governance dibagi menjadi dua bagian yaitu mekanisme internal dan external. Mekanisme internal adalah cara untuk mengendalikan perusahaan dengan menggunakan struktur dan proses internal. Sedangkan mekanisme eksternal adalah cara mempengaruhi perusahaan selain dengan menggunakan mekanisme internal (OECD, 2015). Good corporate governance merupakan sarana untuk mendukung efisiensi ekonomi, pertumbuhan yang berkelanjutan dan stabilitas keuangan perusahaan. Adanya good corporate governance dalam suatu perusahaan akan membantu memfasilitasi perusahaan ke modal investasi jangka panjang, dan membantu memastikan bahwa para pemegang saham dan para pemangku kepentingan lain yang ikut berkontribusi dalam keberhasilan perusahaan telah diperlakukan secara adil (OECD, 2015).

Di Indonesia corporate governance sudah mulai diteliti di dalam perusahaan dan kemudian dikembangkan oleh lembaga peneliti corporate governance, salah satu informasi yang terkait yang dapat digunakan adalah Corporate Governance 
Perception Index (CGPI). Upaya peningkatan Good Corporate Governance di Indonesia, telah dilakukan dengan penilaian indeks tata kelola perusahaan setiap tahunnya. Perusahaan yang mengikuti ajang ini akan masuk dalam Corporate Governance Perception Index (CGPI). Mengacu pada nilai CGPI, para pemegang saham berharap semakin baiknya corporate governance perusahaan akan membuat kinerja perusahaan semakin baik. Kinerja perusahaan yang semakin baik diharapkan mampu meminimalisir praktik manajemen laba sehingga laporan keuangan yang dihasilkan lebih dapat menggambarkan kondisi perusahaan yang sebenarnya (Yudiastuti \& Wirasedana, 2018).

Grand theory dalam penelitian ini adalah teori keagenan. Teori keagenan (agency theory) membahas tentang adanya hubungan keagenan antara principal dan agen. Perspektif hubungan keagenan menjadi dasar yang digunakan untuk memahami corporate governance dan manajemen laba. Hubungan keagenan tercermin antara pihak manajemen (agent) dengan investor (principal) (Naftalia, 2013). Menurut Jensen \& Meckling (1976) teori ini berfokus pada pemisahan kepemilikan dan kontrol. Teori keagenan adalah sebuah kontrak antara manajemen (agent) dengan pemilik (principal). Permasalahan akan muncul ketika investor mendelegasikan manajer untuk pembuatan keputusannya.

Teori keagenan merupakan suatu pemahaman yang menjadi dasar antara keterkaitan good corporate governance dengan manajemen laba. Teori agensi memberikan pandangan bahwa masalah manajemen laba dapat diminimumkan dengan pengawasan sendiri melalui Good Corporate Governance (GCG). Praktik manajemen laba oleh manajemen dapat diminimumkan melalui mekanisme 
monitoring untuk menyelaraskan perbedaan kepentingan pemilik dan manajemen.

Teori akuntansi positif berupaya menjelaskan sebuah proses, yang menggunakan kemampuan, pemahaman, dan pengetahuan akuntansi serta penggunaan kebijakan akuntansi yang paling sesuai untuk menghadapi kondisi tertentu dimasa mendatang. Watts \& Zimmerman (1990) mengajukan tiga hipotesis tentang teori akuntansi positif, yaitu The Bonus Plan Hypothesis, Debt Covenant Hypothesis, dan The Political Cost Hypothesis (Size Hypothesis). Ketiga hipotesis ini yang secara implisit mengakui tiga bentuk keagenan, yaitu antara pemilik dengan manajemen, antara kreditor dengan manajemen, dan antara pemerintah dengan manajemen. Sehingga secara luas, prinsipal bukan hanya pemilik perusahaan, tetapi juga bisa berupa pemegang saham, kreditur, maupun pemerintah. Dari ketiga hipotesis tersebut, leverage dapat dijelaskan dengan hipotesis The Debt to Equity Hypothesis. Hal ini dikarenakan semakin besarnya rasio hutang yang dimiliki oleh suatu perusahaan, maka semakin besar kecenderungan manajer untuk memilih prosedur akuntansi tertentu agar terjadinya perubahan laba yang dilaporkan, hal ini dilakukan untuk menghindari terjadinya pelanggaran kontrak yang telah disepakati.

Leverage adalah hutang yang digunakan oleh perusahaan untuk membiayai asetnya dalam rangka menjalankan aktivitas operasionalnya. Semakin besar hutang perusahaan maka semakin besar pula resiko yang dihadapi pemilik sehingga pemilik akan meminta tingkat keuntungan yang semakin tinggi agar perusahaan tersebut tidak terancam di likuidasi. Jika suatu perusahaan terancam di likuidasi maka yang dapat dilakukan adalah manajemen laba (Gunawan dkk., 
2015).

Keadaan tersebut menunjukkan adanya pengaruh antara leverage dengan manajemen laba. Pernyataan ini didukung dengan hasil penelitian yang dilakukan oleh Anggraeni \& Wardhani (2017), Naftalia (2013), (Putri et al., 2014) Amperaningrum \& Sari (2013), Bestavino (2013), Irawan (2013),dan Agustia (2013) yang memperoleh hasil penelitian bahwa leverage berpengaruh terhadap manajemen laba. Berdasarkan uraian diatas maka hipotesis dalam penelitian ini dapat dirumuskan sebagai berikut:

$\mathrm{H}_{1}$ : Leverage berpengaruh terhadap Manajemen Laba.

Manajemen akan menggunakan suatu metode tertentu untuk mendapatkan laba yang sesuai dengan yang diinginkan oleh manajer, inilah yang dimaksud dengan manajemen laba. Salah satu cara untuk mengurangi terjadinya konflik kepentingan antara agen dan principal adalah dengan diberlakukannya suatu peraturan dan mekanisme pengendalian yang efektif di dalam perusahaan.

Pengimplementasian prinsip-prinsip dan mekanisme corporate governance dalam pengelolaan perusahaan mencerminkan bahwa perusahaan tersebut telah dikelola dengan baik. Adanya pemeringkatan untuk penerapan good corporate governance pada perusahaan mendorong perusahaan untuk memaksimalkan pengimplementasian good corporate governance pada perusahaannya. Pemeringkatan penerapan good corporate governance dilakukan oleh IICG. Dengan diberlakukannya good corporate governance pada setiap perusahaan diharapkan mampu meminimalisir praktek manajemen laba yang terjadi di perusahaan yang dapat merugikan para investor. 
Putu Elsa Pratiwi Dewi dan Ni Gusti Putu Wirawati. Pengaruh ...

Keadaan tersebut menunjukkan Corporate Governance dapat memperlemah hubungan antara leverage dengan manajemen laba. Pernyataan ini didukung dengan hasil penelitian yang dilakukan oleh Yudiastuti \& Wirasedana (2018), Rahmah \& Soekotjo (2017), dan Almadara (2017), dan Naftalia (2013) yang memperoleh hasil penelitian bahwa Corporate Governance memperlemah pengaruh antara leverage terhadap manajemen laba. Berdasarkan uraian diatas maka hipotesis dalam penelitian ini dapat dirumuskan sebagai berikut:

$\mathrm{H}_{2}$ : Corporate Governance dapat memoderasi pengaruh antara Leverage terhadap Manajemen Laba.

\section{METODE PENELITIAN}

Penelitian ini bersifat asosiatif (hubungan) yang bertujuan menjelaskan hubungan variabel melalui pengujian hipotesis yaitu data atau variabel diteliti terlebih dahulu kemudian dijelaskan hubungannya (Sugiyono, 2017:20). Penelitian ini membahas mengenai pengaruh Leverage terhadap Manajemen Laba dengan Corporate Governance sebagai variabel pemoderasi. Berdasarkan teori dan hasil penelitian yang disintesiskan ke dalam rumusan hipotesis, maka model kerangka konsep sebagai dasar penelitian hipotesis seperti gambar berikut:

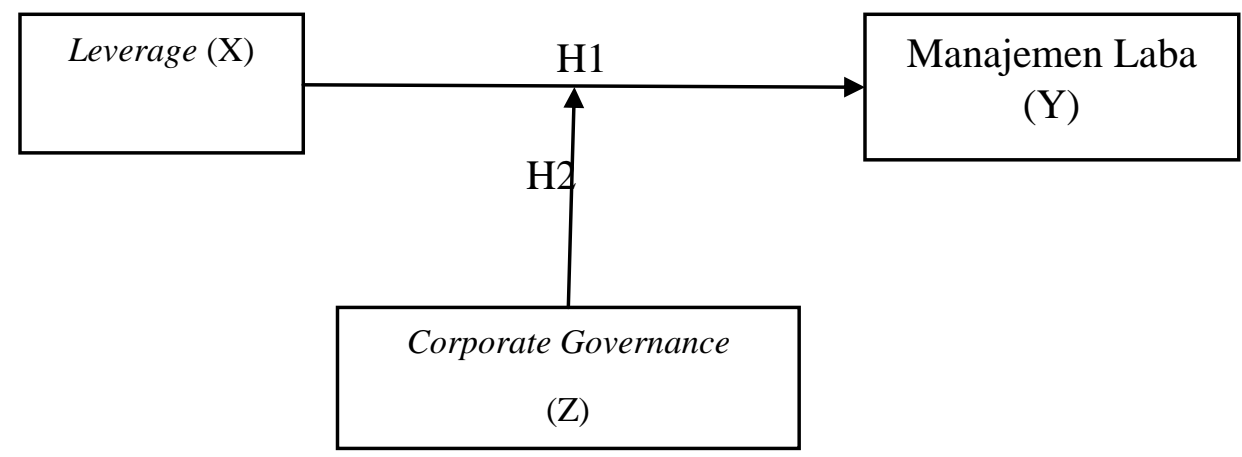

Sumber: Data diolah, 2018

Gambar 1. Kerangka Konseptual 
Lokasi penelitian dilakukan pada perusahaan yang terdaftar dalam penilaian CGPI pada periode 2011-2016. Objek dari penelitian ini adalah Leverage, Corporate Governance dan Manajemen Laba pada pada perusahaan yang terdaftar dalam penilaian CGPI pada periode 2011-2016.

Variabel terikat dalam penelitian ini adalah Manajemen Laba (Y) yang diproksi dengan discretionary accrual dengan menggunakan model Jones yang dimodifikasi (Dechow et al., 2011) dengan langkah sebagai berikut :

$\mathrm{TAC}_{\mathrm{it}}=\mathrm{N}_{\mathrm{it}}-\mathrm{CFO}_{\mathrm{it}}$

Keterangan:

TAC $_{\mathrm{t}} \quad$ : Total accruals perusahaan i pada periode $\mathrm{t}$

$\mathrm{N}_{\mathrm{it}} \quad$ : Laba bersih perusahaan i pada periode $\mathrm{t}$

$\mathrm{CFO}_{\text {it }} \quad$ : Aliran kas dari aktivitas operasi perusahaan i pada periode $\mathrm{t}$

$\mathrm{TAC}_{\mathrm{it}} / \mathrm{A}_{\mathrm{it}-1}=\beta_{1}\left(1 / \mathrm{A}_{\mathrm{it}-1}\right)+\beta_{2}\left(\Delta \mathrm{REV} / \mathrm{A}_{\mathrm{it}-1}\right)+\beta_{3}\left(\mathrm{PPE}_{\mathrm{it}} / \mathrm{A}_{\mathrm{it}-1}\right)+\mathrm{e}$

Keterangan:

TAC $_{\mathrm{t}} \quad$ : Total accruals perusahaan i pada periode $\mathrm{t}$

$\mathrm{A}_{\mathrm{it}-1} \quad$ : Total Aset perusahaan i pada periode $\mathrm{t}-1$

$\triangle \mathrm{REV}_{\mathrm{t}} \quad:$ Perubahaan pendapatan perusahaan i dari tahun $\mathrm{t}-1$ ke tahun $\mathrm{t}$

$\mathrm{PPE}_{\mathrm{it}} \quad:$ Aset tetap perusahaan tahun $\mathrm{t}$

$\beta_{1-3} \quad:$ Koefisien regresi

e : error

$\mathrm{NDA}_{i t}=\beta_{1}\left(1 / \mathrm{A}_{\mathrm{it}-1}\right)+\beta_{2}\left(\Delta \mathrm{REV}_{\mathrm{t}} / \mathrm{A}_{\mathrm{it}-1}-\Delta \mathrm{REC}_{\mathrm{t}} / \mathrm{A}_{\mathrm{it}-1}\right)+\beta_{3}\left(\mathrm{PPE}_{\mathrm{it}} / \mathrm{A}_{\mathrm{it}-1}\right)$

Keterangan:

$\mathrm{NDA}_{\mathrm{it}} \quad$ : Non-Discretionary Accruals perusahaan i pada periode ke $\mathrm{t}$

$\mathrm{A}_{\mathrm{it}-1} \quad$ : Total Aset perusahaan i pada periode $\mathrm{t}$

$\triangle \mathrm{REV}_{\mathrm{t}} \quad:$ Perubahaan pendapatan perusahaan dari tahun $\mathrm{t}-1$ ke tahun $\mathrm{t}$

$\triangle \mathrm{REC}_{\mathrm{t}} \quad:$ Perubahan piutang perusahaan i dari tahun $\mathrm{t}-1$ ke tahun $\mathrm{t}$

$\mathrm{PPE}_{\mathrm{it}} \quad:$ Aset tetap perusahaan tahun $\mathrm{t}$

$\beta_{1-3} \quad$ : Koefisien regresi

$\mathrm{DA}_{\mathrm{it}}=\mathrm{TAC}_{\mathrm{it}} / \mathrm{A}_{\mathrm{it}-1}-\mathrm{NDA}_{\mathrm{i}}$

Keterangan:

$\mathrm{DA}_{\mathrm{it}} \quad$ : Discretionary Accruals perusahaan i pada periode ke $\mathrm{t}$ 
$\mathrm{TAC}_{\mathrm{it}} \quad$ : Total accrual perusahaan i pada tahun $\mathrm{t}$

$\mathrm{A}_{\mathrm{it}-1} \quad$ : Total Aset perusahaan i pada periode $\mathrm{t}$

$\mathrm{NDA}_{\mathrm{it}} \quad$ : Non-discretionary accruals pada tahun $\mathrm{t}$

Variabel bebas dalam penelitian ini adalah Leverage (X) diukur dengan menggunakan Debt to Equity Ratio. Alasan digunakannya Debt to Equity Ratio untuk mengukur leverage karena dapat mengetahui seberapa besar tingkat penggunaan hutang perusahaan terhadap total modal sendiri. Adapun rumusnya adalah sebagai berikut:

Debt to Equity Ratio = Total Liability / Total Equity

Variabel moderasi dalam penelitian ini adalah Corporate Governance (Z) diukur menggunakan score CGPI perusahaan dalam penilaian The Indonesian Most Trusted Companies Corporate Gonvernance Perception Index (CGPI) yang dipublikasikan oleh majalah SWA. Alasan digunakan Corporate Gonvernance Perception Index dikarenakan laporan yang dilakukan oleh IICG dapat memberikan gambaran secara langsung mengenai penerapan GCG di dalam perusahaan. Rating level pada CGPI yaitu Sangat Terpercaya (85,00-100), Terpercaya $(70,00-84,99)$ dan Cukup Terpercaya $(55,00-69,99)$.

Populasi dalam penelitian ini adalah seluruh perusahaan non keuangan yang terdaftar di BEI periode 2011-2016. Teknik pengambilan sampel dalam penelitian ini adalah teknik purposive sampling yaitu data dipilih berdasarkan kriteria tertentu yang sesuai dengan tujuan penelitian. Metode pengumpulan data yang digunakan dalam penelitian ini adalah metode observasi non partisipan dengan cara melihat, mempelajari uraian-uraian dari buku, jurnal, skripsi, tesis serta mengutip catatan-catatan yang diperoleh dari Bursa Efek Indonesia (BEI) yang 
berupa laporan keuangan tahunan perusahaan dan daftar perusahaan yang terdaftar dalam penilaian CGPI.

Jenis data yang digunakan dalam penelitian ini adalah data kuantitatif meliputi laporan keuangan tahunan perusahaan yang terdaftar dalam penilaian CGPI yang terdaftar di Bursa Efek Indonesia tahun 2011-2016. Sedangkan sumber data yang digunakan dalam penelitian ini adalah data sekunder berupa laporan keuangan tahunan perusahaan yang terdaftar dalam penilaian CGPI yang terdaftar di Bursa Efek Indonesia tahun 2011-2016 melalui situs resminya www.idx.co.id.

Teknik analisis data yang digunakan untuk memecahkan permasalahan yang terdapat dalam penelitian ini adalah teknik analisis MRA (Moderating Regression Analysis) dengan menggunakan Statistical Product and Service Solution (SPSS). Moderated Regression Analysis (MRA) dalam persamaan regresinya mengandung unsur interkasi dengan persamaan sebagai berikut:

$Y=\alpha+\beta_{1} X+\beta_{2} Z+\beta_{3} X^{8} Z+\varepsilon$

Keterangan:

Y : Manajeman Laba

$\alpha \quad$ : Konstanta

$\mathrm{X} \quad$ : Leverage

$\mathrm{Z} \quad$ : Corporate Governance

$\beta 1-\beta 3$ : Koefisien Regresi

Sebelum dilakukan pengujian hipotesis, data terlebih dahulu diuji asumsi klasik. Hal ini dilakukan untuk menghindari terjadinya estimasi bias mengingat tidak semua data dapat diterapkan regresi. Pengujian asumsi klasik meliputi uji normalitas, uji autokorelasi dan uji heteroskedastisitas. 


\section{HASIL DAN PEMBAHASAN}

Penelitian ini menggunakan sampel yang memenuhi kriteria pemilihan sampel yang telah ditentukan sebelumnya. Berdasarkan observasi penelitian yang dilakukan, maka perusahaan yang dapat dijadikan sampel adalah sebanyak 5 perusahaan dengan proses penyeleksian sebagai berikut:

\section{Tabel 1.}

\section{Hasil Seleksi Pemilihan Sampel}

\begin{tabular}{llc}
\hline No & \multicolumn{1}{c}{ Kriteria } & $\begin{array}{c}\text { Jumlah } \\
\text { Perusahaan }\end{array}$ \\
\hline 1. & Perusahaan yang terdaftar dalam Bursa Efek Indonesia (BEI) & 555 \\
2. & Perusahaan keuangan yang terdaftar dalam Bursa Efek Indonesia (BEI) & $(77)$ \\
3. & $\begin{array}{l}\text { Perusahaan go publik non keuangan di BEI yang tidak terdaftar dalam } \\
\text { pemeringkatan CGPI secara berturut turut tahun 2011-2016 }\end{array}$ & $(473)$ \\
& $\begin{array}{l}\text { Jumlah sampel penelitian } \\
\text { Total sampel dalam enam tahun penelitian }\end{array}$ & 5 \\
& & 30
\end{tabular}

Sumber: Data diolah, 2018

Rincian nama-nama perusahaan yang dijadikan sampel dalam penelitian ini disajikan dalam Tabel 2 sebagai berikut:

Tabel 2.

Nama Perusahaan Sampel

\begin{tabular}{ccl}
\hline No. & Kode & \multicolumn{1}{c}{ Nama Perusahaan } \\
\hline 1. & ANTM & PT Aneka Tambang (Persero) Tbk \\
2. & PTBA & PT Bukit Asam (Persero) Tbk \\
3. & TLKM & PT Telekomunikasi Indonesia (Persero) Tbk \\
4. & JSMR & PT Jasa Marga (Persero) Tbk \\
5. & BNBR & PT Bakrie and Brother Tbk \\
\hline
\end{tabular}

Sumber: Data diolah, 2018

Statistik deskriptif berhubungan dengan pengumpulan dan peringkat data yang menggambarkan karakteristik sampel yang digunakan dalam penelitian ini. Analisis ini berguna untuk menjelaskan karateristik sampel terutama mencakup nilai rata-rata (mean), nilai ektrim yaitu nilai minimum dan nilai maksimum, serta standar deviasi dari masing-masing variabel. Hasil dari statistik deskriptif tersebut dapat dilihat pada Tabel 3. berikut ini: 
Tabel 3.

Statistik Deskripstif Variabel-Variabel Penelitian

\begin{tabular}{lrrrrr}
\hline & N & \multicolumn{1}{c}{ Minimum } & Maximum & \multicolumn{1}{c}{ Mean } & Std. Deviation \\
\hline MANAJEMEN & 30 & $-0,0471$ & 1,0296 & 0,3134 & 0,3559 \\
LABA & & & & & \\
LEVERAGE & 30 & $-6,8626$ & 2,2744 & 0,3473 & 2,1936 \\
CG & 30 & 69,2200 & 91,2000 & 8,2425 & 7,5779 \\
LEV*CG & 30 & $-4,7805$ & 195,8508 & 3,6220 & 159,4083 \\
Valid N & 30 & & & & \\
Sumber: Data diolah, 2018 & & & &
\end{tabular}

Nilai minimum variabel manajemen laba adalah $-0,0471$ yaitu PT Jasa Marga (Persero) Tbk pada tahun 2012, dan nilai maksimumnya adalah 1,0296 yang terdapat pada PT Telekomunikasi Indonesia (Persero) Tbk pada tahun 2011. Mean untuk manajemen laba adalah 0,3134 hal ini berarti rata-rata manajemen laba pada sampel amatan yang digunakan dalam penelitian ini berjumlah 0,3134. Deviasi standar untuk manajemen laba adalah 0,3559 yang memiliki makna dimana terjadi penyimpangan nilai manajemen laba pada nilai rata-ratanya sebesar 0,3559 .

Nilai minimum variabel leverage adalah $-6,8626$ yaitu PT Bakrie and Brother Tbk pada tahun 2013, dan nilai maksimumnya adalah 2,2744 yang terdapat pada PT Jasa Marga (Persero) Tbk pada tahun 2016. Mean untuk leverage adalah 0,3474 hal ini berarti rata-rata leverage pada sample amatan yang digunakan dalam penelitian ini berjumlah 0,3473. Deviasi standar untuk leverage adalah 2,1936 yang memiliki makna dimana terjadi penyimpangan nilai leverage pada nilai rata-ratanya sebesar 2,1936 .

Nilai minimum variabel Corporate Governance adalah 69,2200 yaitu PT Bakrie and Brother Tbk pada tahun 2012, dan nilai maksimumnya adalah 91,2000 yang terdapat pada PT Telekomunikasi Indonesia (Persero) Tbk pada tahun 2016. 
Mean untuk Corporate Governance adalah 8,2425 hal ini berarti rata-rata Corporate Governance pada sample amatan yang digunakan dalam penelitian ini berjumlah 8,2425. Deviasi standar untuk Corporate Governance adalah 7,5779 yang memiliki makna dimana terjadi penyimpangan nilai Corporate Governance pada nilai rata-ratanya sebesar 7,5779.

Uji normalitas bertujuan untuk menguji apakah variabel pengganggu (residual) dari model regresi berdistribusi normal atau tidak. Uji normalitas dalam penelitian ini menggunakan Kolmogorov-Smirnov test. Hasil uji normalitas dari penelitian ini disajikan dalam Tabel 4. berikut:

Tabel 4.

Hasil Uji Normalitas

\begin{tabular}{|c|c|c|}
\hline \multicolumn{3}{|c|}{ Unstandardized Residual } \\
\hline $\mathrm{N}$ & & 30 \\
\hline \multirow[t]{3}{*}{ Normal Parameters ${ }^{\mathrm{a}, \mathrm{b}}$} & Mean & 0,2060 \\
\hline & Std. & 0,11402 \\
\hline & Deviation & \\
\hline \multirow[t]{3}{*}{ Most Extreme Differences } & Absolute & 0,119 \\
\hline & Positive & 0,119 \\
\hline & Negative & $-0,088$ \\
\hline Kolmogorov-Smirnov Z & & 0,652 \\
\hline Asymp. Sig. (2-tailed) & & 0,789 \\
\hline
\end{tabular}

Sumber: Data diolah, 2018

Data penelitian yang digunakan dikatakan berdistribusi normal apabila apabila nilai Asymp. Sig. (2-tailed) lebih besar dari $\alpha=0,05$. Berdasarkan Tabel 4. di atas, nilai Asymp. Sig. (2-tailed) dari model persamaan yang diuji sebesar 0,789 lebih besar dari 0,05 . Hal ini menunjukkan data yang digunakan dalam penelitian ini telah berdistribusi normal.

Uji Autokorelasi bertujuan menguji apakah dalam model regresi linear ada korelasi antara kesalahan pengganggu pada periode $\mathrm{t}$ dengan kesalahan pengganggu pada periode t-1 (Ghozali, 2016:107). Jika suatu model regresi 
mengandung gejala autokorelasi, maka prediksi yang dilakukan dengan model tersebut akan tidak baik atau dapat memberikan hasil prediksi yang menyimpang. Adapun hasil pengujian autokorelasi dari penelitian ini disajikan pada Tabel 5 . sebagai berikut

Tabel 5.

Hasil Uji Autokorelasi

\begin{tabular}{rrrrrr}
\hline Model & $\mathrm{R}$ & $\mathrm{R}$ Square & $\begin{array}{c}\text { Adjusted R } \\
\text { Square }\end{array}$ & $\begin{array}{c}\text { Std. Error of } \\
\text { the Estimate }\end{array}$ & $\begin{array}{l}\text { Durbin- } \\
\text { Watson }\end{array}$ \\
\hline 1 & $0,481^{\mathrm{a}}$ & 0,551 & 0,143 & 0,10555 & 1,676 \\
\hline
\end{tabular}

Sumber: Data diolah, 2018

Berdasarkan hasil uji autokorelasi pada Tabel 5. di atas, nilai dw yang dihasilkan sebesar 1,676. Oleh karena jumlah $\mathrm{n}=30$ dan $\mathrm{k}=2$, diperoleh nilai $\mathrm{d}_{\mathrm{L}}$ $=1,28$ dan $d_{u}=1,57$ sehingga diperoleh juga nilai $4-d_{u}=2,43$, maka dapat dirumuskan kriteria $d_{u}<d w<4-d_{u}$ yaitu $(1,57<1,676<2,43)$. Hal ini menunjukkan data yang digunakan pada penelitian ini bebas dari autokorelasi.

Uji Heteroskedastisitas bertujuan menguji apakah dalam model regresi terjadi ketidaksamaan variance dari residual satu pengamatan ke pangamatan yang lain. Suatu model regresi yang mengandung gejala heteroskedastisitas dapat memberikan hasil prediksi yang menyimpang. Adapun hasil pengujian heteroskedastisitas disajikan pada Tabel 6 .

Tabel 6.

Hasil Uji Heterokedastisitas

\begin{tabular}{|c|c|c|c|c|c|c|}
\hline \multirow{2}{*}{\multicolumn{2}{|c|}{ Model }} & \multicolumn{2}{|c|}{$\begin{array}{c}\text { Unstandardized } \\
\text { Coefficients }\end{array}$} & \multirow{2}{*}{$\begin{array}{c}\begin{array}{c}\text { Standardized } \\
\text { Coefficients }\end{array} \\
\text { Beta }\end{array}$} & \multirow[t]{2}{*}{$\mathbf{T}$} & \multirow[t]{2}{*}{ Sig. } \\
\hline & & B & $\begin{array}{l}\text { Std. } \\
\text { Error }\end{array}$ & & & \\
\hline 1 & (Constant) & 0,206 & 1,348 & & 0,153 & 0,880 \\
\hline & Leverage & $-1,187$ & 2,297 & $-4,927$ & $-0,517$ & 0,610 \\
\hline & Kualitas CG & 0,000 & 0,016 & $-0,004$ & $-0,007$ & 0,995 \\
\hline & $\mathrm{LEV} * \mathrm{CG}$ & 0,013 & 0,027 & 4,673 & 0,489 & 0,629 \\
\hline
\end{tabular}

Sumber: Data diolah, 2018 
Berdasarkan hasil uji heteroskedastisitas pada Tabel 6. di atas, dapat diketahui nilai signifikansi dari variabel leverage sebesar 0,610 $(>0,05)$, nilai signifikansi dari variabel Corporate Governance sebesar 0,995 (>0,05), dan nilai signifikansi dari variabel interaksi yakni sebesar 0,629 (>0,05). Oleh karena nilai signifikansi dari masing-masing variabel independen terhadap variabel absolute residual berada diatas 0,05 maka dapat disimpulkan bahwa data yang digunakan pada penelitian ini tidak terdapat masalah heteroskedastisitas.

Penelitian ini menggunakan Moderated Regression Analysis (MRA) dalam model persamaan regresi linear berganda untuk mengetahui kemampuan Corporate Governance dalam memoderasi pengaruh leverage terhadap manajemen laba. Hasil pengujian disajikan dalam rekapitulasi hasil analisis regresi regresi linear berganda dengan menggunakan uji interaksi pada Tabel 7.

Berdasarkan hasil yang diperoleh dari rekapitulasi hasil analisis regresi linear berganda berdasarkan pada hasil analisis koefisien regresi pada Tabel 7. adalah sebagai berikut:

$$
\mathrm{Y}=-0,552-0,300 \mathrm{LEV}+0,010 \mathrm{CG}-0,002 \mathrm{LEV} \cdot \mathrm{CG}+\varepsilon
$$

Tabel 7.

Rekapitulasi Hasil MRA

\begin{tabular}{|c|c|c|c|c|c|}
\hline \multirow[t]{2}{*}{ Model } & \multirow{2}{*}{$\begin{array}{l}\text { Unstandardized } \\
\text { Coefficients }\end{array}$} & \multirow{2}{*}{ Std. Error } & \multirow{2}{*}{$\begin{array}{l}\text { Standardized } \\
\text { Coefficients } \\
\text { Beta }\end{array}$} & \multirow[t]{2}{*}{$\mathbf{t}$} & \multirow[t]{2}{*}{ Sig. } \\
\hline & & & & & \\
\hline (Constant) & $-0,552$ & 0,574 & & $-0,961$ & 0,346 \\
\hline Leverage & $-0,300$ & 0,085 & $-0,574$ & $-3,528$ & 0,002 \\
\hline Kualitas CG & 0,010 & 0,007 & 0,222 & 1,474 & 0,153 \\
\hline $\mathrm{LEV}^{*} \mathrm{CG}$ & $-0,002$ & 0,000 & $-0,988$ & $-6,009$ & 0,000 \\
\hline Adjusted $\mathrm{R}^{2}$ & 0,551 & & & & \\
\hline $\mathrm{F}_{\text {hitung }}$ & 10,626 & & & & \\
\hline Sig. F & 0,000 & & & & \\
\hline
\end{tabular}

Sumber: Data diolah, 2018 
Berdasarkan persamaan diatas, dapat dijelaskan hal-hal sebagai berikut yaitu nilai konstanta -0,552 menunjukan bahwa bila leverage dan Corporate Governance sama dengan nol, maka manajemen laba akan menurun sebesar 0,552 satuan. Nilai koefisien regresi LEV sebesar $-0,300$ menunjukan bahwa bila leverage naik satu satuan, maka manajemen laba akan mengalami penurunan sebesar 0,300 satuan dengan asumsi variabel lainnya konstan. Nilai koefisien regresi CG sebesar 0,010 menunjukan bahwa bila Corporate Governance naik satu satuan, maka manajemen laba akan mengalami peningkatan sebesar 0,010 satuan dengan asumsi variabel lainnya konstan. Nilai koefisien regresi LEV.CG sebesar -0,002 menunjukan bahwa bila interaksi antara leverage dengan Corporate Governance naik satu satuan, maka manajemen laba akan mengalami penurunan sebesar 0,002 satuan dengan asumsi variabel lainnya konstan.

Uji kelayakan model (Uji F) bertujuan untuk menguji apakah model yang digunakan dalam penelitian ini layak atau tidak untuk digunakan sebagai alat analisis dalam menguji pengaruh variabel independen pada variabel dependennya. Adapun hasil dari pengujian kesesuaian model dalam penelitian ini telah disajikan pada Tabel 7. Berdasarkan hasil uji kesesuaian model pada Tabel 7. di atas, dapat dilihat bahwa nilai dari uji F sebesar 10,626 dan nilai $p$-value (Sig. F) yakni 0,000 lebih kecil dari nilai $\alpha=0,05$. Hal ini menunjukkan bahwa model persamaan dalam penelitian ini layak untuk digunakan.

Analisis koefisien determinasi digunakan untuk mengukur seberapa jauh kemampuan semua variabel bebas dalam menerangkan variasi dari variabel 
dependennya (Ghozali, 2016:95). Dalam penelitian ini koefisien determinasi dilihat melalui nilai adjusted $R$ square. Adapun nilai dari adjusted $R$ square pada penelitian ini telah disajikan pada Tabel 7. Berdasarkan pada Tabel 7. diatas, dapat dilihat bahwa nilai dari adjusted $R$ square sebesar 0,551 dimana memiliki arti bahwa 55,1\% variasi perubahan manajemen laba dapat dijelaskan oleh variabel leverage dan Corporate Governance. Sedangkan sisanya sebesar 44,9\% dipengaruhi oleh variabel lain diluar dari model regresi yang digunakan.

Berdasarkan Tabel 7. diperoleh nilai t hitung sebesar -3,528 sedangkan nilai t tabel sebesar 2,048 dan nilai signifikansi uji t yakni nilai p-value sebesar 0,002 lebih kecil dari $\alpha=0,05$ serta nilai koefisien regresi sebesar $-0,300$. Ini berarti bahwa leverage berpengaruh negatif terhadap manajemen laba, sehingga hipotesis pertama dalam penelitian ini diterima.

Semakin besar rasio leverage menunjukkan semakin besar tingkat ketergantungan perusahaan terhadap pihak eksternal (kreditur) dan semakin besar pula beban biaya hutang (biaya bunga) yang harus dibayar oleh perusahaan. Semakin meningkatnya rasio leverage maka hal tersebut berdampak terhadap profitabilitas yang diperoleh perusahaan, karena sebagian digunakan untuk membayar bunga pinjaman. Terdapat beberapa proksi yang digunakan untuk mengukur leverage, dalam penelitian ini menggunakan Debt to Equity Ratio (DER) dalam mengukur tingkat leverage.

Hasil penelitian ini menunjukan bahwa koefisien regresi variabel leverage sebesar -0,300 dan leverage berpengaruh negatif terhadap manajemen laba dengan tingkat signifikansi yang diperoleh yakni sebesar 0,002 lebih kecil dari $\alpha=0,05$. 
Hasil ini menerima hipotesis $\mathrm{H}_{1}$ yakni leverage berpengaruh terhadap manajemen laba. Ini artinya dengan adanya rasio leverage maka akan mempengaruhi praktik manajemen laba yang dilakukan manajer. Dalam penelitian ini menunjukan angka negatif signifikan, yang artinya apabila perusahaan memiliki hutang yang tinggi perusahaan memerlukan bantuan dana dari pihak ketiga baik kreditur ataupun investor. Upaya untuk mendapatkan kepercayaan dari kreditur atau investor perusahaan akan mengurangi tindakan manajemen laba, karena apabila perusahaan melakukan praktik manajemen laba maka kreditur atau investor cenderung tidak mempercayai laporan yang diberikan oleh perusahaan.

Hasil penelitian ini sejalan dengan hasil penelitian yang dilakukan oleh Wiyadi et al. (2015) yang menyatakan leverage berpengaruh negatif signifikan terhadap manajemen laba pada seluruh perusahaan selain perbankan yang terdaftar di Bursa Efek Indonesia. Selain hasil penelitian wiyadi, hasil penelitian yang dilakukan oleh Wildarman (2013), Amperaningrum \& Sari (2013) dan Rahmah \& Soekotjo (2017) juga menyatakan bahwa leverage berpengaruh negatif terhadap manajemen laba.

Berdasarkan Tabel 7. diperoleh nilai t hitung sebesar -6,009 sedangkan nilai t tabel sebesar 2,048 dan nilai signifikansi uji t yakni nilai p-value sebesar 0,000 lebih kecil dari $\alpha=0,05$ serta nilai koefisien regresi sebesar -0,002. Ini berarti bahwa Corporate Governance mempengaruhi hubungan antara leverage terhadap manajemen laba, sehingga hipotesis kedua dalam penelitian ini diterima.

Hasil pengujian dengan menggunakan Moderated Regression Analysis (MRA) menunjukan bahwa koefisien regresi variabel interaksi antara variabel 
leverage dengan Corporate Governance sebesar -0,002 dengan nilai signifikansi sebesar 0,000 lebih kecil dari $\alpha=0,05$. Hasil ini menerima hipotesis $\mathrm{H}_{2}$ yakni Corporate Governance mampu memoderasi pengaruh leverage terhadap manajemen laba.

Berdasarkan jenis variabel moderasi Corporate Governance dalam penelitian ini, variabel Corporate Governance dapat digolongkan sebagai variabel moderasi prediktor yaitu variabel moderasi yang berperan sebagai variabel independen (prediktor) dalam hubungan yang dibentuk. Hal ini dapat dilihat dari nilai signifikansi Corporate Governance sebesar 0,153 dan serta interaksi Corporate Governance dengan leverage yakni sebesar 0,000. Corporate Governance mampu memperlemah maupun memperkuat pengaruh leverage terhadap manajemen laba. Corporate Governance dalam penelitian ini di proksikan dengan Corporate Governance Perception Index (CGPI) yang berarti proksi mampu memberikan batasan atau kontrol kepada pihak manajemen dalam melakukan tindakan opportunistik.

Penelitian ini bertentangan dengan hasil penelitian yang dilakukan oleh Yudiastuti \& Wirasedana (2018) dan Rahmah \& Soekotjo (2017) yang menyatakan Corporate Governance tidak mampu memoderasi terjadinya praktik manajemen laba. Namun hasil penelitian ini sejalan dengan hasil penelitian yang dilakukan oleh Putri dkk. (2015) dan Naftalia (2013) yang menyatakan bahwa Corporate Governance terbukti mampu memoderasi terjadinya praktik manajemen laba. Hal ini disebabkan kemampuan Corporate Governance dalam memoderasi pengaruh leverage terhadap manajemen laba diduga disebabkan 
karena nilai Corporate Governance Perception Index (CGPI) sebagai hasil survei dari The Indonesian Institute of Corporate Governance (IICG) yang mencerminkan tata kelola perusahaan yang sesungguhnya pada tahun terkait. Karena adanya penilaian tata kelola perusahaan tersebut maka perusahaan akan melakukan tata kelola dengan sangat baik agar penilaian yang diberikan juga semakin baik.

\section{SIMPULAN}

Berdasarkan pembahasan hasil penelitian di atas, dapat disimpulkan bahwa Leverage dengan menggunakan Debt to Equity Ratio (DER) memiliki pengaruh negatif signifikan terhadap manajemen laba. Apabila perusahaan memiliki hutang yang tinggi perusahaan memerlukan bantuan dana dari pihak ketiga baik kreditur ataupun investor. Upaya untuk mendapatkan kepercayaan dari kreditur atau investor perusahaan akan mengurangi tindakan manajemen laba, karena apabila perusahaan melakukan praktik manajemen laba maka kreditur atau investor cenderung tidak mempercayai laporan yang diberikan oleh perusahaan. Corporate Governance mampu memoderasi pengaruh leverage terhadap manajemen laba. Kemampuan Corporate Governance dalam memoderasi pengaruh leverage terhadap manajemen laba diduga disebabkan karena nilai Corporate Governance Perception Index (CGPI) sebagai hasil survei dari The Indonesian Institute of Corporate Governance (IICG) yang mencerminkan tata kelola perusahaan yang sesungguhnya pada tahun terkait. Karena adanya penilaian tata kelola perusahaan tersebut maka perusahaan akan melakukan tata kelola dengan sangat baik agar penilaian yang diberikan juga semakin baik. Pelitian ini menggunakan Corporate 
Putu Elsa Pratiwi Dewi dan Ni Gusti Putu Wirawati. Pengaruh ...

Governance Perception Index (CGPI) sebagai pengukuran dari Corporate Governance. Peneliti selanjutnya diharapkan menggunakan perhitungan yang berbeda karena adanya keterbatasan sampel yang didapatkan dengan menggunakan Corporate Governance Perception Index tersebut. Keterbatasan sampel dikarenakan terdapat beberapa perusahaan yang tidak terdaftar dalam penilaian CGPI secara berturut-turut. Selain itu peneliti selanjutnya juga dapat menggunakan variabel lain yang dapat mempengaruhi praktik manajemen laba selain leverage. Bagi perusahaan di Indonesia diharapkan untuk lebih bersungguhsungguh dalam menerapkan konsep Corporate Governance. Perusahaan juga dianjurkan untuk ikut serta dalam penilaian Corporate Governance yang dilakukan oleh The Indonesian Institute of Corporate Governance (IICG) agar memeroleh skor pemeringkatan Corporate Governance Perception Index (CGPI). Hal ini penting karena bagi pihak eksternal, dengan pemeringkatan tersebut dapat memberikan gambaran tentang penerapan Corporate Governance di dalam perusahaan dan dapat menjadi nilai tambah dimata investor. Investor dalam mengambil keputusan dalam berinvestasi, sebaiknya tidak hanya melihat dari informasi keuangannya saja. Namun juga tetap melihat aspek non keuangan seperti penerapan Corporate Governance yang dilakukan oleh perusahaan. Karena apabila Good Corporate Governance di suatu perusahaan baik maka pengawasan dan control terhadap kinerja agen akan baik. Hal ini sebagai salah satu cara untuk menekan tindakan oportunistik manajemen. 


\section{REFERENSI}

Abbadi, S., Hijazi, Q., \& Al-Rahahleh, A. (2016). Corporate Governance Quality and Earnings Management: Evidence from Jordan. Australasian Accounting, Business and Finance Journal, 10(2), 54-75.

Agustia, D. (2013). Pengaruh Faktor Good Corporate Governance, Free Cash Flow, dan Leverage Terhadap Manajemen Laba. Jurnal Akuntansi Dan Keuangan, 15(1), 27-42.

Almadara. (2017). Pengaruh Leverage Terhadap Manajemen Laba Dengan Corporate Governance Sebagai Variabel Moderasi. Jurnal Ekonomi Universitas Negeri Yogyakarta, 3(1), 237-245.

Amertha, I. S. P., Ulupui, I. G. K. A., \& Putri, I. G. A. M. A. (2014). Analysis of firm size, leverage, corporate governance on earnings management practices ( Indonesian evidence). Journal Of Economics, Business and Accountancy Ventura, 17(2), 259-268.

Amidreza, V., \& Mortazavi, M. S. S. (2016). The Impact of Financial Leverage on Accrual-Based and Real Earnings Management. International Journal of Academic Research in Accounting, Finance and Management Sciences, 6(2), 53-60.

Amperaningrum, I., \& Sari, I. K. (2013). Pengaruh Good Corporate Governance , Leverage, dan Kinerja Keuangan terhadap Manajemen Laba ( Studi Kasus pada Perusahaan Perbankan yang Terdaftar di Bursa Efek Indonesia. Prosiding PESAT (PSikologi, Ekonomi, Sastra, Arsitekrur \& Teknik Sipil), 5(1), 294-302.

Anggraeni, M. D., \& Wardhani, R. (2017). The effect of leverage and IFRS convergence on earnings management through real activities manipulation in Asia. Asian Journal of Business and Accounting, 10(1), 87-125.

Ardison, kym marcel, Martinez, A. L., \& Galdi, F. C. (2012). The effect of leverage on earnings management in Brazil. Advances in Scientific and Applied Accounting, 4(1), 305-324.

Bestavino. (2013). Pengaruh Ukuran Perusahaan, Profitabilitas, Dan Leverage Operasi Terhadap Perataan Laba Pada Perusahaan Manufaktur Di Bei. Jurnal Ilmiah Mahasiswa Akuntansi, 1(4), 101-106.

Dechow, P., Hutton, A., Kim, J. H., \& Sloan, R. G. (2011). Detecting earnings management: A new approach. Journal of Accounting, 50(1), 275-334.

Enekwe, Innocent, C., Agu, Ikechukwu, C., \& Nnagbogu, E. K. (2014). The 
Effect of Financial Leverage on Financial Performance: Evidence of Quoted Pharmaceutical Companies in Nigeria. Journal of Economics and Finance, 5(3), 17-25.

FCGI. (2001). Corporate Governance: Tata Kelola Perusahaan (3rd ed.). Jakarta.

Fischer, M. ., \& Rosenzweig, K. (1995). Attitudes Practitioners Acceptability of Students and Accounting the Ethical Management Marilyn Fischer Concerning of Earnings. Journal of Business Ethics, 14(6), 433-444.

Gajevszky, A. (2014). The Impact of auditor's opinion on earnings management: Evidence from Romania. Network Intelligence Studies, 3(1), 61-73.

Ghozali, I. (2016a). Aplikasi Analisis Multivariate dengan Program IBM SPSS 21 (Edisi ke-8). Semarang: Badan Penerbit Universitas Diponegoro.

Ghozali, I. (2016b). Aplikasi Analisis Multivariete (8th ed.). Semarang: Badan Penerbit UNDIP.

Gul, F. A., Chen, C. J. P., \& Tsui, J. S. L. (2003). Discretionary Accounting Accruals, Managers' Incentives, and Audit Fees. Contemporary Accounting Research, 20(3), 441-464.

Gunawan, I. K., Ari, N., Darmawan, S., Gusti, I., \& Purnamawati, A. (2015). Pengaruh Ukuran Perusahaan, Profitabilitas, Dan Leverage Terhadap Manajemen Laba Pada Perusahaan Manufaktur Yang Terdaftar Di Bursa Efek Indonesia (Bei). Journal S1 Ak Universitas Pendidikan Ganesha Jurusan Akuntansi Program S1, 03(01).

Healy, P. M., \& Wahlen, J. M. (1999). A Review of the Earnings Management Literature and Its. Accounting Horizons, 13(4), 365-383.

Hrp, A. I., Sadalia, I., \& Fachrudin, K. A. (2017). The Effect of Leverage and Financial Distress on Earnings Management with Good Corporate Governance as the Moderating Variable. Academic Journal of Economic Studies, 3(4), 86-95.

https://davidparsaoran.wordpress.com. (2009). Skandal Manipulasi Laporan Keuangan PT. Kimia Farma Tbk. Retrieved from https://davidparsaoran.wordpress.com/2009/11/04/skandal-manipulasilaporan-keuangan-pt-kimia-farma-tbk/ diakses pada tanggal 1 Juni 2018

Https://finance.detik.com. (2010). Katarina Diduga Manipulasi Laporan Keuangan Auditan 2009. Retrieved from https://finance.detik.com/bursadan-valas/d-1427631/katarina-diduga-manipulasi-laporan-keuangan-auditan2009 diakses pada tanggal 1 Juni 2018 
Irawan, W. A. (2013). Analisis Pengaruh Kepemilikan Institusional , Leverage , Ukuran Perusahaan dan Profitabilitas terhadap Manajemen Laba. Skripsi Ilmiah Universitas Diponegoro.

Jensen. Michael. (1986). Agency Costs of Free Cash Flow, Corporate Finance, and Takeovers. The American Economic Review, 76(2), 323-329.

Jensen, M. C., \& Meckling, W. H. (1976). Theory of the Firm: Managerial Behavior, Agency Costs and Ownership Structure. Journal of Financial Economics, 3(4), 305-360.

Jones, S., \& Sharma, R. (2001). The impact of free cash flow, financial leverage and accounting regulation on earnings management in Australia's "old" and "new" economies. Managerial Finance, 27(12), 18-39.

Lestari \& Wirawati, S. D. (2016). Good Corporate Governance Sebagai Pemoderasi Pengaruh Asimetri Informasi Pada Manajemen Laba. E-Jurnal Akuntansi Universitas Udayana, 16(1), 156-182.

Naftalia, V. C. (2013). Pengaruh Leverage Terhadap Manajemen Laba Dengan Corporate Governance Sebagai Variabel Pemoderasi. Diponegoro Journal Of Accounting, 2(3), 1-11.

Nazir, M. (2014). Metode Penelitian. Bogor: Ghalia Indonesia.

OECD. (2015). G20/OECD Principles of Corporate Governance. OECD Publishing.

Pasaribu, R. B. F., Kowanda, D., \& Firdaus, M. (2015). Mekanisme Good Corporate Governance , Ukuran Perusahaan , Struktur Kepemilikan Manajerial Dan Perbankan Di Bursa Efek Indonesia. Jrmb, 10(1), 1-22.

Patrick, E. A., Paulinus, E. C., \& Nympha, A. N. (2015). The Influence of Corporate Governance on Earnings Management Practices: A Study of Some Selected Quoted Companies in Nigeria. American Journal of Economics Finance and Management, 1(5), 482-493.

Prastyawan, D. T., \& Saraswati, E. (2013). Pengaruh Leverage, Ukuran Perusahaan, dan Kualitas Audit Terhadap Manajemen Laba. Jurnal Ilmiah Mahasiswa Fakultas Ekonomi Dan Bisnis Universitas Brawijaya, 3(1), 122223.

Puri \& Gayatri, A. R. (2018). Good Corporate Governance Memoderasi Pengaruh Financial Distress Terhadap Manajemen Laba. E-Jurnal Akuntansi Universitas Udayana, 23(1), 489-512. 
Putri, A. A. S., Sari, P., Bagus, I., \& Astika, P. (2015). Moderasi Good Corporate Governance Pada Pengaruh Antara Leverage Dan Manajemen Laba. EJurnal Akuntansi Universitas Udayana, 12(3), 752-769.

Putri, I. D., \& Sofyan, S. (2013). Analisis Pengaruh Struktur Dan Mekanisme Good Corporate Governance, Ukuran Perusahaan Dan Leverage Terhadap Manajemen Laba. Diponegoro Journal Of Management, 2(2), 1-16.

Rahmah, L., \& Soekotjo, H. (2017). Pengaruh Leverage Terhadap Earnings Management Dengan Corporate Governance Sebagai Variabel Moderasi. Jurnal Ilmu Dan Riset Manajemen, 6(2), 55-63.

Scott, R. W. (2009). Financial Accounting Theory (5th ed.). New Jersey: PrenticeHall.

Setiawati, L., \& Naim, A. (2001). Bank Health Evaluation By Bank Indonesia and Earning Management in Banking Industry. Gadjah Mada International Journal of Business, 3(2), 159-176.

Sugiyono. (2017). Metode Penelitian Bisnis. (Suryandari, Ed.). Bandung: ALFABETA.

Veronica, A. (2015). The Influence of Leverage and Its Size on the Earnings Management. Research Journal of Finance and Accounting, 6(8), 159-167.

Wahyono, R. E. S. (2012). Pengaruh Corporate Governance Terhadap Manajemen Laba Di Industri Perbankan Indonesia. Jrnal Ilmu \& Riset Akuntansi, 1(12), $1-21$.

Watts, R. L., \& Zimmerman, J. L. (1990). Positive Accounting Theory: A Ten Year Perspective. The Accounting Review, 65(1), 131-156.

Wildarman, D. (2013). Pengaruh Profitabilitas, Leverage, Dan Asimetri Informasi Terhadap Manajemen Laba (Studi Empiris Pada Perusahaan Manufaktur yang terdaftar di Bursa Efek Indonesia Periode 2009 - 2013). Jurusan Akuntansi Fakultas Ekonomi Universitas Bung Hatta, 6(1).

Wiyadi, Trisnawati, Sasongko, \& Fauzi. (2015). Profitability and Employee Stock Ownership on Earnings Management. International Journal of Business and Management and Law, 8(2), 21-30.

Yudiastuti \& Wirasedana, L. N. (2018). Good Corporate Governance Memoderasi Pengaruh Leverage Terhadap Manajemen Laba. E-Jurnal Akuntansi Universitas Udayana, 23(1), 130-155. 
Yuniarti, E., Mukhtaruddin, \& Hanim, N. (2017). Effect on Value Earnings Management Company with Good Corporate Governance Practices as Moderating Variable. SHS Web of Conferences, 34, 04007.

Zamri, N., Rahman, R. A., \& Isa, N. S. M. (2013). The Impact of Leverage on Real Earnings Management. Procedia Economics and Finance, 7(Icebr), 8695. 